\title{
Color Removal from Groundwater by Coagulation and Oxidation Processes
}

\author{
Jacek Leszczyński ${ }^{1}$ \\ 1 Bialystok University of Technology, ul. Wiejska 45E, 15-351 Białystok, Poland \\ e-mail: j.leszczynski@pb.edu.pl
}

\begin{abstract}
The paper concerns the experimental research related to the removal of color and permanganate index $\left(\mathrm{COD}_{\mathrm{Mn}}\right)$ in the presence of iron and manganese from the underground water by means of coagulation and ozonation. The tests were carried out on a laboratory and technical scale in the real underground water treatment system. Ozone, as a strong oxidizing agent, was used to reduce the color intensity and to convert the iron $\mathrm{Fe}^{2+}$ and manganese ions $\mathrm{Mn}^{2+}$ to $\mathrm{Fe}(\mathrm{OH})_{3}$ and $\mathrm{MnO}_{2}$, respectively. In order to optimally remove the color to a value below $15 \mathrm{mg} / \mathrm{L}$, the ozone dose of $3 \mathrm{mg} / \mathrm{L}$ was sufficient, which also ensured the proper removal of iron and manganese, by $94 \%$ and $83 \%$, respectively. However, ozonation conducted under these conditions, did not provide sufficient removal of organic compounds expressed as $\mathrm{COD}_{\mathrm{Mn}}$ below the assumed value of $3 \mathrm{mg} / \mathrm{L}$. The effect of aluminum sulfate and polyaluminum chloride (PAC) was also studied, as a result of which it was found that polyaluminum chloride proved to be more effective reagent. Under the technical conditions of water purification at a dose of $16 \mathrm{mg} / \mathrm{L}$ coagulant, the efficiency of color removal was $65.2 \%$ and $\mathrm{COD}_{\mathrm{Mn}}-50.8 \%$, which ensured that the values of the tested indicators in the purified water were maintained below the permissible level.
\end{abstract}

Keywords: groundwater treatment, color removal, coagulation, ozone

\section{INTRODUCTION}

The composition of groundwater is mainly shaped by the hydrochemical as well as physical and biological processes. One of the factors affecting the chemical composition of groundwater is the dissolution of minerals. The biological and biochemical changes occurring with the participation of microorganisms are other important processes. Microorganisms participate in the majority of oxidation-reduction processes, which in many cases, determine the migration of elements and their compounds [Appelo and Postma 2005, Tekerlekopoulou at al. 2013]. The main groundwater contamination is dissolved gases, mainly $\mathrm{CO}_{2}$, iron and manganese compounds, and to a lesser extent, natural organic matter (NOM), the source of which are usually humic substances that give the groundwater color and elevated $\mathrm{COD}_{\mathrm{Mn}}$ values. Humic substances infiltrate into the groundwater as a result of leaching from the brown coal of peat deposits, as well as from the soils abundant in humus [Pisarek and Głowacki 2015, Tekerlekopoulou at al. 2013].

The presence of organic compounds in groundwater may adversely affect its taste and smell, which may lead to the secondary development of bacteria in the water distribution system. Moreover, they may be precursors of the by-products arising e.g. during water disinfection [Świetlik 2004, Hua 2007, Chiang at al. 2009]. Among the contaminants found in groundwater, color significantly complicates the technological process, forcing the use of the treatment methods characteristic of surface waters [Dąbrowska 2016, Sillanpää 2018, Szlachta and Adamski 2009]. The effective methods of removing the color originating from humic compounds include chemical oxidation processes using ozone, sorption processes on granular activated carbons, coagulation and membrane processes. Often, only a combination of several methods allows to obtain the appropriate water quality [Sillanpää et al. 2018, Kaleta 2017, Krupińska 2012, Pietrzyk and Papciak 2018, Piekutin 2013]. 
Among the above-mentioned processes, the coagulation carried out directly in the filter bed together with the removal of iron and manganese is used to remove the organic pollutants from underground water. However, this process requires the use of special contact filters. The effectiveness of coagulation depends on many factors, e.g. $\mathrm{pH}$ and temperature of water, type and dose of coagulant, contact time, type of filter filling, and many other parameters, the impact of which often determines the efficiency of the process [Matilainen et al. 2010, Libecki and Dziejowski 2008, Świderska-Bróż et al. 2008]. The effectiveness of coagulation also depends on the chemical composition of water, e.g. higher content of calcium and magnesium in water improves the removal efficiency of humic substances [Kaleta and Puszkarewicz 2019].

The most commonly used coagulants are based on hydrolyzable aluminum and iron salts, including aluminum sulfate and iron(III) sulfate. For the proper course of coagulation with these reagents, it is necessary to have a proper natural alkalinity ensuring their hydrolysis. This requirement is not always met; therefore, it is often necessary to correct the alkalinity before coagulation. In addition, a right reaction time is required for the proper hydrolysis of these coagulants. In this situation, the so-called pre-hydrolyzed coagulants as polyaluminum chloride, can be applied [Ivancev-Tumbas 2001, Nowacka 2014, Matilainen et al. 2010, Ghernaout et al. 2009]. Polyaluminum chlorides are also polymerized coagulants. As a result of their use, a larger amount of hydrolysis products is also formed than using traditional aluminum coagulants [Yan et al. 2008]. Most NOMs can be removed by coagulation, although the hydrophobic fraction and compounds with high molecular weight are removed more efficiently than the hydrophilic fraction and compounds with low molecular weight [Sillanpää et al. 2018].

Ozonation is a recognized method used to remove color as well as reduce the concentration of disinfectant by-products from chlorine compounds. Ozone also reacts with organic substances, which leads to their increased biodegradability. The use of the ozonation process as pre-oxidation additionally improves the taste and smell of water and has a positive effect on the effectiveness of coagulation. In groundwater, ozone can be used in addition to the oxidation of iron and manganese as well as sulfides, nitrites, arsenic and bromide ions. However, ozonation of the NOM-containing water can lead to the formation of aldehydes, ketones and carboxylic acids, as well as bromides and bromates. Therefore, this process is usually combined with coagulation and sorption on biologically active carbon filters to effectively eliminate the ozonation by-products [Chiang at al. 2009].

The aim of the present study was to examine the possibility of removing the color and $\mathrm{COD}_{\mathrm{Mn}}$ in a real underground water treatment system including aeration and a two-stage filtration process using coagulation and ozonation.

\section{MATERIALS AND ANALYTICAL METHODS}

The water for tests came from an underground intake located in northeastern Poland. The intake consists of two deep wells with an operational capacity of approximately $100 \mathrm{~m}^{3} / \mathrm{h}$. In the existing technological system, water is treated by aeration and two-stage filtration on quartz filters and filters with a catalytic bed. A dosing system for sodium hypochlorite is provided for a periodic disinfection of water. The treated water is collected in the equalizing tank, from where it is pumped to the network with a set of multi-stage pumps.

$$
\text { Hydrated aluminum sulfate }
$$
$\left(\mathrm{Al}_{2}\left(\mathrm{SO}_{4}\right)_{3} \times 18 \mathrm{H}_{2} \mathrm{O}\right)$, polyaluminum chloride (PAC), 95-97\% $\mathrm{H}_{2} \mathrm{SO}_{4}(\mathrm{w} / \mathrm{w})$ and $\mathrm{NaOH}$ were used in the technological test. During the tests: $\mathrm{pH}$, color, turbidity, iron, manganese, permanganate index $\left(\mathrm{COD}_{\mathrm{Mn}}\right)$, ammonium ion and nitrate were determined. The analytical tests were carried out according to the standard procedure [APHA 1998]. The pH-meter (Hach session 4) was used for the $\mathrm{pH}$ determination, while the turbidity was determined with the nephelometric method using the WTW 550 IR device. The color was determined on the platinum-cobalt scale using the Hach DR 4000 spectrophotometer. The concentration of ozone in the air-ozone mixture was determined by means of the iodometric method [International Ozone Association 1987]. The basic statistical analysis included calculation of mean value and standard deviation. The achieved test results represent an average of at least three repetitions, and the standard deviation of measured values did not exceed $5 \%$ level.

\section{Experimental procedures}

The tests were carried out on a laboratory scale and under technical conditions at a water 
treatment station. In the initial laboratory tests, reagents and process parameters were selected, such as reagent type, dose, contact time and $\mathrm{pH}$. Then, the results of laboratory experiments were applied in the real technological system of the water supply station. As a criterion satisfying the purification efficiency, the following were assumed: color $\leq 15 \mathrm{mgPt} / \mathrm{L}$ and $\mathrm{COD}_{\mathrm{Mn}}$ $\leq 3.0 \mathrm{mgO}_{2} / \mathrm{L}$.

The experimental tests on a laboratory scale were carried out in technological systems including aeration, coagulation and filtration as well as ozonation and filtration. Aluminum sulfate and polyaluminum chloride (PAC) were used in the coagulation process. The doses of aluminum sulfate and PAC were $4-20 \mathrm{mg} / \mathrm{L}$ based on $\mathrm{Al}_{2} \mathrm{O}_{3}$. Coagulation was carried out in the water samples after aeration in a system including the step of fast and slow mixing, sedimentation, decanting and filtration. In the first phase of the process, the sample water, together with the reagent, was mixed intensively for $2 \mathrm{~min}$ at a speed of about $100 \mathrm{rpm}$, then slowly with an intensity of about $35 \mathrm{rpm}$ in the assumed time of 10 and 15 minutes. Sedimentation time was 60 minutes. Before the coagulation, water was aerated using a ceramic diffuser for 15 minutes.

Ozonation was carried out in a static system in $1 \mathrm{~L}$ water samples. The installation consisted of a contact chamber with a diameter of $0.05 \mathrm{~m}$ equipped with a ceramic diffuser with a diameter of $30 \mathrm{~mm}$. The source of ozone was an ozonator with a capacity of approximately 6 $\mathrm{g} \mathrm{O}_{3} / \mathrm{h}$. During the tests, the flow of ozone was $0.5 \mathrm{~L} / \mathrm{min}$, the concentration of ozone in the air-ozone mixture was $1.0 \mathrm{mgO}_{3} / \mathrm{L}$. Dose of the oxidant was determined by the ozonation time, which was from 4 to $10 \mathrm{~min}$, providing a dose of 2 to $5 \mathrm{mgO}_{3} / \mathrm{L}$.

The tests in the real system were carried out using aluminum sulfate and polyaluminum chloride applying the doses of reagents determined on the basis of preliminary tests. Each time after determining the assumed dose of the coagulant, several research series were carried out and the obtained water samples were subjected to analytical determinations. The water for analytical tests was collected after $60 \mathrm{~min}$ utes of pump operation, which ensured proper water exchange in fast filters.

\section{RESULTS AND DISCUSSION}

\section{Characteristics of water}

The results of the raw water tests are presented in Table 1 . The raw water was characterized by an increased color in the range of 26-28 $\mathrm{mgPt} / \mathrm{L}$ and the $\mathrm{COD}_{\mathrm{Mn}}$ value in the range 6.4-6.8 $\mathrm{mgO}_{2} / \mathrm{L}$, also contained elevated iron and manganese concentrations, $3.4-3.8 \mathrm{mgFe} / \mathrm{L}$ and $0.28-0.32 \mathrm{mgMn} / \mathrm{L}$, respectively. According to the tests carried out at the water treatment plant, the technological system used effectively removes iron and manganese compounds, and there were no exceedances of ammonium ion and turbidity. At the same time, the organic compounds that give it an increased color and $\mathrm{COD}_{\mathrm{Mn}}$ above the acceptable level, remain in the treated water.

\section{Laboratory tests}

During the tests, two aluminum coagulants were tested, and tests were carried out using ozone to remove color and to oxidize iron and manganese. Due to the short contact time that can be achieved during the filtration of water in the real technological system, the tests were carried out at two reaction times of 10 and 15 minutes. The initial color and $\mathrm{COD}_{\mathrm{Mn}}$ values in raw water were $27 \mathrm{mg} / \mathrm{L}$ and $6.6 \mathrm{mg} / \mathrm{L}$, respectively. The effectiveness of color and $\mathrm{COD}_{\mathrm{Mn}}$ removal after the coagulation process using aluminum sulfate and polyaluminum chloride, depending on the dose of coagulants and the reaction time, is shown in Figure 1. The reduction of color due to aluminum sulfate to values below $15 \mathrm{mg} / \mathrm{L}$ was obtained at a dose of $16 \mathrm{mg} / \mathrm{L}$ of coagulant after 15 minutes of reaction; however, the water still contained an over-norm $\mathrm{COD}_{\mathrm{Mn}}$ value above $5 \mathrm{mg} / \mathrm{L}$. The lowest $\mathrm{COD}_{\mathrm{Mn}}$ content of $4.1 \mathrm{mg} / \mathrm{L}$ was recorded at

Table 1. Characteristics of the raw water

\begin{tabular}{|c|c|c|}
\hline Parameter & Value & $\begin{array}{l}\text { Standard } \\
\text { deviation }\end{array}$ \\
\hline $\mathrm{pH}$ & 6.7 & 0.1 \\
\hline Color (Pt-Co units) & 27 & 1 \\
\hline Turbidity (NTU) & 2.33 & 0.58 \\
\hline $\mathrm{COD}_{\mathrm{Mn}}\left(\mathrm{mg} \mathrm{O}_{2} / \mathrm{L}\right)$ & 6.6 & 0.2 \\
\hline Iron (mg Fe/L) & 3.6 & 0.2 \\
\hline Manganese (mg Mn/L) & 0.3 & 0,02 \\
\hline Nitrate $\left(\mathrm{mg} \mathrm{NO}_{3}^{-} / \mathrm{L}\right)$ & 1.07 & 0.23 \\
\hline $\begin{array}{l}\text { Ammonium ion } \\
\left(\mathrm{mg} \mathrm{NH}_{4}^{+} / \mathrm{L}\right)\end{array}$ & 0.5 & 0.1 \\
\hline
\end{tabular}




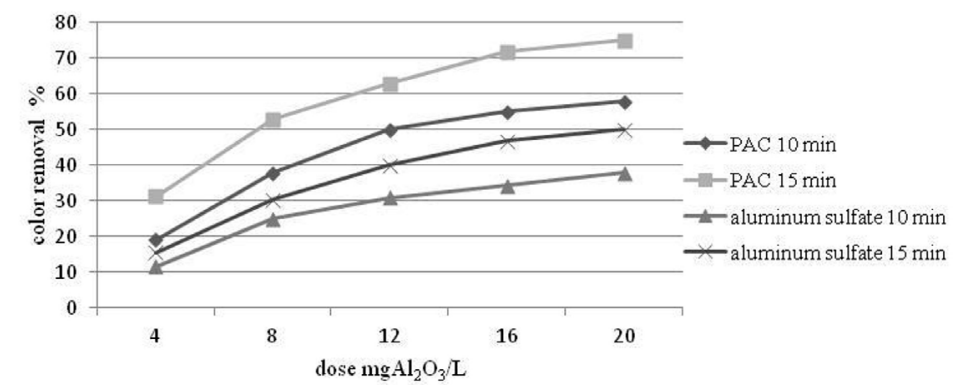

Fig. 1. Comparison of the color removal efficiency using polyaluminum chloride and aluminum sulfate depending on the dose of coagulants and contact time

this reaction time using a dose of $20 \mathrm{mg} / \mathrm{L}$ of coagulant. In this case, the effect of color reduction and $\mathrm{COD}_{\mathrm{Mn}}$ was $50 \%$ and $37.5 \%$, respectively. With a reaction time of 10 minutes and the highest dose of aluminum sulfate $(20 \mathrm{mg} / \mathrm{L})$, the color removal efficiency was $38 \%$ and the $\mathrm{COD}_{\mathrm{Mn}}$ $23.1 \%$; thus, the values of these indicators in the treated water were $16.7 \mathrm{mg} / \mathrm{L}$ and $5.1 \mathrm{mg} / \mathrm{L}$, and it still exceeded the assumed levels. In addition, in the case of the water after coagulation with a shorter contact time, the turbidity increased above 3 NTU already at a dose of $12 \mathrm{mg} / \mathrm{L}$. The effect of removing the color and $\mathrm{COD}_{\mathrm{Mn}}$ shown in Figures 1 and 2 does not proceed in proportion to the amount of coagulant introduced; therefore, further increasing the dose of aluminum sulfate seems unjustified.

In the case of polyaluminum chloride, the proper color removal efficiency was obtained at the $8 \mathrm{mg} / \mathrm{L}$ dose and the contact time of $15 \mathrm{~min}$ utes. A slightly higher dose of $12 \mathrm{mg} / \mathrm{L}$ was required to lower the color below $15 \mathrm{mg} / \mathrm{L}$ with a reaction time of $10 \mathrm{~min}$. The maximum reduction of color at a dose of $20 \mathrm{mg} / \mathrm{L}$ at the longest and the shortest contact times was $75 \%$ and $58 \%$, respectively. On the other hand, lowering the $\mathrm{COD}_{\mathrm{Mn}}$ to the assumed value at a longer reaction time was obtained using a dose of polyaluminum chloride of $16 \mathrm{mg} / \mathrm{L}$. In the second case, even at a dose of $20 \mathrm{mg} / \mathrm{L}, \mathrm{COD}_{\mathrm{Mn}}$ was $3.3 \mathrm{mg} / \mathrm{L}$, which exceeded the assumed value. At the same time, in the case of polyaluminum chloride, even at the highest dose, the turbidity of water after the process did not exceed 1 NTU.

The studies carried out by Rucka at al. [2019] also indicate the high efficiency of polyaluminum chloride in the removal of humic substances, which for TOC were in the range of $37.2-59.4 \%$ and $20.0-41.5 \%$ for pre-hydrolyzed and hydrolyzing coagulants, respectively. Moreover, the effect increased along with the molecular weight of humic substances present in water. According to the Nowacka and Włodarczyk-Makuła [2014], application of pre-hydrolyzed aqueous solutions of aluminum polychlorosulfate Flokor $1 \mathrm{SAW} / \mathrm{B}$, Flokor $105 \mathrm{~V}$ during the coagulation process, allowed to improve the water quality in comparison with unhydrolyzed aluminum sulfate(VI). At the same time, the dose of these coagulants was lower by $36.4 \%$. Higher efficacy of pre-hydrolyzed coagulants is also confirmed by other studies [Duan and Gregory 2003, Nowacka et al. 2014].

Ozonation and filtration of water proved to be a very effective process for removing the color, iron and manganese. The results of the tests are presented in Figure 3. The initial color and COD values in raw water were $27 \mathrm{mg} / \mathrm{L}$ and $6.4 \mathrm{mg} / \mathrm{L}$, respectively. After the process, the color value in the assumed range of $<15 \mathrm{mg} / \mathrm{L}$ was obtained already at the ozone dose of $3 \mathrm{mgO}_{3} / \mathrm{L}$. The applied

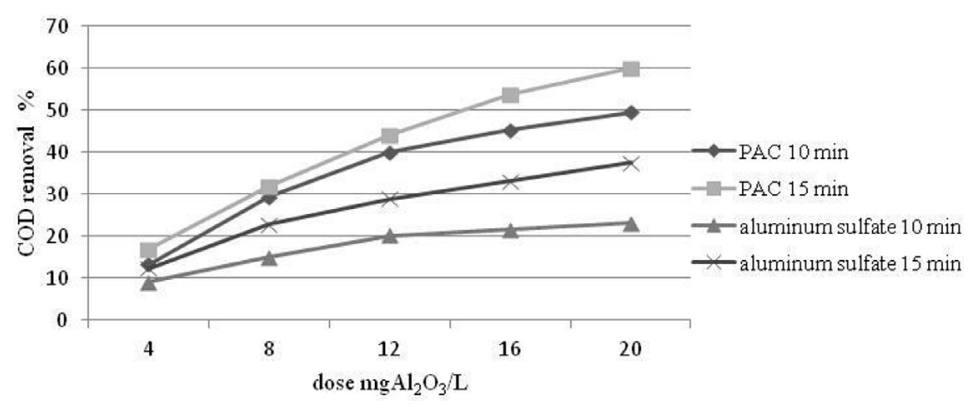

Fig. 2. Comparison of the $\mathrm{COD}_{\mathrm{Mn}}$ removal efficiency using polyaluminum chloride and aluminum sulfate depending on the dose of coagulants and contact time 


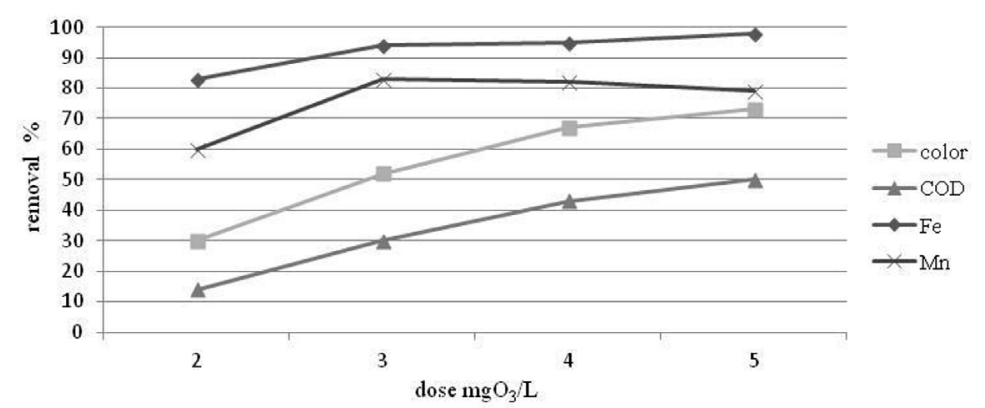

Fig. 3. Effect of ozone dose on the removal of color, $\mathrm{COD}_{\mathrm{Mn}}$, Fe and $\mathrm{Mn}$

dose also ensured the effective removal of iron and manganese to $0.2 \mathrm{mg} / \mathrm{L}$ and $0.04 \mathrm{mg} / \mathrm{L}$, respectively. However, the $\mathrm{COD}_{\mathrm{Mn}}$ value in this case still exceeded the assumed value and amounted to $4.5 \mathrm{mg} / \mathrm{L}$. Even the highest dose of ozone used did not allow the $\mathrm{COD}_{\mathrm{Mn}}$ to fall below $3 \mathrm{mg} / \mathrm{L}$. The highest reduction efficiency of this indicator at the $5 \mathrm{mg} / \mathrm{L}$ ozone dose was $50 \%$, which ensured the removal of $\mathrm{COD}_{\mathrm{Mn}}$ to the value of $3.2 \mathrm{mg} / \mathrm{L}$. In the case of color, $\mathrm{Fe}$ and $\mathrm{Mn}$, the effect at this dose of ozone was $73 \%, 98 \%$ and $79 \%$, respectively. However, such a high dose of ozone in the presence of organic compounds may lead to the formation of the unwanted oxidation by-products [Sadrnourmohamadi and Gorczyca 2015, Ivancev-Tumbas and Dalmacija 2001]. In addition, in the waters containing manganese, the use of high doses of ozone can lead to the oxidation of manganese to $\mathrm{Mn}^{7+}$, which results in a decrease in the manganese removal efficiency and may lead to the appearance of a pink color. This effect was observed at the dose of $4 \mathrm{mgO}_{3} / \mathrm{L}$, where the concentration of manganese was higher than at the dose of $3 \mathrm{mgO}_{3} / \mathrm{L}$. For the optimal removal of iron and manganese, Araby et al. [2009] used a dose of $3 \mathrm{mg} / \mathrm{L}$ ozone, which ensured removal of iron and manganese by $96 \%$ and $83 \%$, respectively. These studies also confirmed the fact that the effectiveness of manganese removal above $3.5 \mathrm{mgO}_{3} / \mathrm{L}$ was reduced.

\section{Technological tests on a real scale}

The results of the technological tests conducted on a technical scale in the real system of the water treatment station are presented in Tables 2, 3 as well as in Figures 4 and 5. During the tests, slight fluctuations in color in the range of $25-28 \mathrm{mg} / \mathrm{L}$ in raw water were found, which required a correction of the established doses of reagents. The main tests were carried out at the maximum observed color of $28 \mathrm{mg} / \mathrm{L}$ and $\mathrm{COD}_{\mathrm{Mn}} 6.4 \mathrm{mg} / \mathrm{L}$. The results of coagulation studies with aluminum sulfate and polyaluminum chloride confirm the conclusions obtained in laboratory tests, where significantly higher efficiency was obtained using polyaluminum chloride,

Table 2. Values of selected indicators of water quality after coagulation using polyaluminum chloride

\begin{tabular}{|l|c|c|c|c|c|}
\hline \multirow{2}{*}{\multicolumn{1}{|c|}{ Parameter }} & \multicolumn{5}{c|}{ Dose $\left[\mathrm{mg} \mathrm{Al}_{2} \mathrm{O}_{3} / \mathrm{L}\right]$} \\
\cline { 2 - 6 } & 4 & 8 & 12 & 16 & 20 \\
\hline Color (Pt-Co units) & 18 & 15 & 12 & 9 & 8 \\
\hline Turbidity $(\mathrm{NTU})$ & $<1$ & $<1$ & 1 & 1 & 2 \\
\hline $\mathrm{COD}_{\mathrm{Mn}}\left(\mathrm{mg} \mathrm{O}_{2} / \mathrm{L}\right)$ & 4.8 & 4.3 & 3.8 & 3.1 & 2.8 \\
\hline Iron $(\mathrm{mg} \mathrm{Fe} / \mathrm{L})$ & 0.1 & 0.05 & 0.1 & 0.1 & 0.05 \\
\hline Manganese $(\mathrm{mg} \mathrm{Mn} / \mathrm{L})$ & 0.02 & 0.01 & 0.03 & 0.05 & 0.07 \\
\hline
\end{tabular}

Table 3. Values of selected indicators of water quality after coagulation using aluminum sulfate

\begin{tabular}{|l|c|c|c|c|c|}
\hline \multirow{2}{*}{ Parameter } & \multicolumn{5}{|c|}{ Dose $\left[\mathrm{mg} \mathrm{Al}_{2} \mathrm{O}_{3} / \mathrm{L}\right]$} \\
\cline { 2 - 6 } & 4 & 8 & 12 & 16 & 20 \\
\hline Color (Pt-Co units) & 22 & 19 & 18 & 16 & 15 \\
\hline Turbidity (NTU) & $<1$ & 1 & 2 & 3 & 5 \\
\hline $\mathrm{COD}_{\mathrm{Mn}}\left(\mathrm{mg} \mathrm{O}_{2} / \mathrm{L}\right)$ & 5.4 & 5.2 & 4.7 & 4.4 & 4.2 \\
\hline Iron $(\mathrm{mg} \mathrm{Fe} / \mathrm{L})$ & 0.2 & 0.1 & 0.1 & 0.2 & 0.2 \\
\hline Manganese $(\mathrm{mg} \mathrm{Mn} / \mathrm{L})$ & 0.02 & 0.01 & 0.05 & 0.07 & 0.08 \\
\hline
\end{tabular}




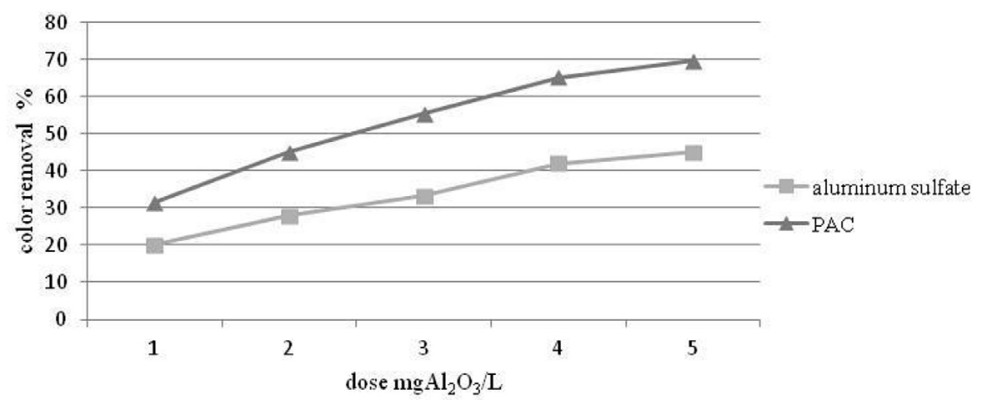

Fig. 4. Effect of coagulant doses on the extent of color removal

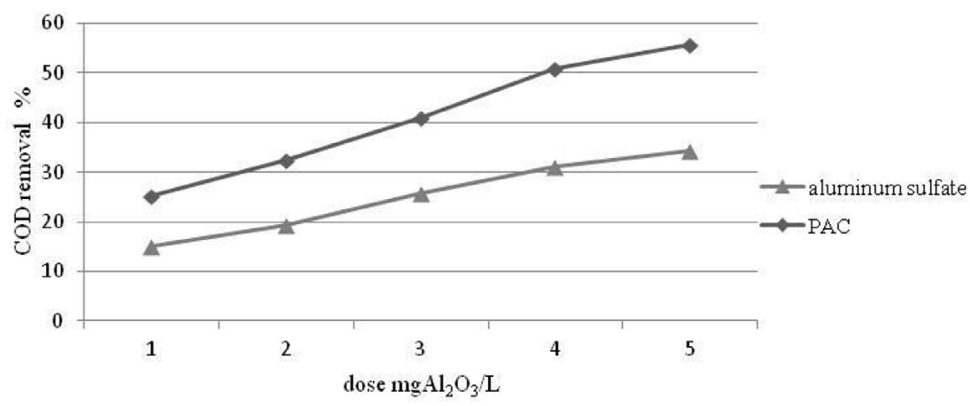

Fig. 5. Effect of coagulant doses on the extent of $\mathrm{COD}_{\mathrm{Mn}}$ removal

especially with shorter reaction times. In this case, the color value of $15 \mathrm{mg} / \mathrm{L}$ was obtained already at a dose of $8 \mathrm{mg} / \mathrm{L}$ coagulant. Using aluminum sulfate, the color at the level of $15 \mathrm{mg} / \mathrm{L}$ was recorded only at a dose of $20 \mathrm{mg} / \mathrm{L}$. At the same time, by dosing the aluminum sulfate, already at a dose of $12 \mathrm{mg} / \mathrm{L}$ in water after the second degree of filtration, increased turbidity above 2 NTU appeared. Similarly to the laboratory tests, the effect was also significantly worse in relation to $\mathrm{COD}_{\mathrm{Mn}}$. Only polyaluminum chloride allowed to lower the $\mathrm{COD}_{\mathrm{Mn}}$ to the assumed value of $3 \mathrm{mg} / \mathrm{L}$. This effect was obtained at a dose of $20 \mathrm{mg} / \mathrm{L}$ of coagulant. However, the use of such a high dose of coagulant increased the turbidity in water after the process to 2 NTU. Therefore, under the conditions discussed, the dose of polyaluminum chloride should not exceed $16 \mathrm{mg} / \mathrm{L}$. In this case, the $\mathrm{COD}_{\mathrm{Mn}}$ was $3.1 \mathrm{mg} / \mathrm{L}$, which only slightly exceeded the assumed value of $3 \mathrm{mg} / \mathrm{L}$. Regardless of the applied dose of both aluminum sulfate and polyaluminum chloride, the iron concentration did not exceed the permissible values and was at the highest dose of coagulants -0.2 and $0.05 \mathrm{mgFe} / \mathrm{L}$, respectively. The concentration of manganese after coagulation with aluminum sulfate did not exceed the limit value of $0.05 \mathrm{mg} / \mathrm{L}$ at a dose of $12 \mathrm{mg} / \mathrm{L}$, whereas after the use of polyaluminum chloride at the dose of $16 \mathrm{mg} / \mathrm{L}$. In both cases, higher doses of coagulants resulted in a decrease in the manganese removal efficiency.

\section{CONCLUSIONS}

The currently operated underground water treatment system, together with installed devices, ensures effective removal of iron and manganese, while the values of color and CODMn are still elevated above the permissible limits in the treated water.

Preliminary laboratory tests showed the possibility of effective removal of color and $\mathrm{COD}_{\mathrm{Mn}}$ to the values assumed using PAC at the dose of $16 \mathrm{mg} / \mathrm{L}$. In this case, reduction of these indicators was $71.7 \%$ and $53.8 \%$, respectively. The use of ozone also proved to be an effective way to remove color, iron and manganese; however, water still had an increased $\mathrm{COD}_{\mathrm{Mn}}$ value after the process, higher than assumed one, even at a dose of $5 \mathrm{mg} \mathrm{O}_{3} / \mathrm{L}$. In addition, the use of ozone at the treatment station would require a thorough reconstruction of the existing technological system. However, the advantage of this process would be the possibility of giving up the second stage of filtration designed to remove manganese.

In the existing technological system, removing the color without significant investment outlays is possible only with the use of coagulation carried out in the currently used filter beds. The experiments on a technical scale showed greater efficiency of polyaluminum chloride dosed before the first stage of filtration. The assumed color values of less than 15 $\mathrm{mg} / \mathrm{L}$ were obtained with a dose of polyaluminum 
chloride $-8 \mathrm{mgAl}_{2} \mathrm{O}_{3} / \mathrm{L}$, while $\mathrm{COD}_{\mathrm{Mn}}$ removal to $3.1 \mathrm{mg} / \mathrm{L}$ level required a dose of $16 \mathrm{mg} / \mathrm{L}$.

\section{REFERENCES}

1. APHA (American Public Health Association) 1998. Standard Methods for the Examination of Water and Wastewater. American Public Health Association, Washington, DC.

2. Appelo C.A.J., Postma D. 2005. Geochemistry, groundwaterand pollution. Taylor\&Francis, Amsterdam.

3. Araby R.El., Hawash S., Diwani G.El. 2009. Treatment of iron and manganese in simulated groundwater via ozone technology. Desalination, 249(3), 1345-1349.

4. Chiang P.C., Chang E.E., Chang P.C., and Huang, C.P. 2009. Effects of pre-ozonation on the removal of THM precursors by coagulation. Sci. Total Environ., 407(21), 5735-5742.

5. Dąbrowska L. 2016. Removal of organic matter from surface water using coagulants with various basicity. J Ecol Eng., 17(3), 66-72.

6. Duan J., Gregory J. 2003. Coagulation by hydrolyzing metal salts. Adv. Colloid Interface Sci., 100-102, 475-502.

7. Ghernaout D., Ghernaout B., Kellil A. 2009. Natural organic matter removal and enhanced coagulation. Desalin. Water Treat., 2, 203-222.

8. Hua G., Reckhow D.A. 2007. Characterization of disinfection byproduct precursors based on hydrophobicity and molecular size. Environ Sci Technol., 41, 3309-3315.

9. International Ozone Association 1987. Standardisation Committee-Europe: Iodometric Method for the Determination of Ozone in a Process Gas, 001/87.

10. Ivancev-Tumbas I., Dalmacija B. 2001. Effects of coagulation processes on aldehydes formation in groundwater treated with common oxidative agents. Water Res., 35, 3950-3958.

11. Kaleta J., Puszkarewicz A. 2019. Inflence of Water Hardness on the Effctiveness of Coagulation of Humic Compounds. J. Ecol. Eng., 20(6), 126-134.

12. Kaleta J., Papciak D., Puszkarewicz A. 2017. Evalution of the effiency of the adsorption process in removing humic substances from water. Ecological Engineering 18(4), 107-115.

13. Krupińska I. 2012. Suitability of Coagulation for Treatment of Groundwater. Rocznik Ochrona Środowiska, 14, 491-501.

14.Libecki B., Dziejowski J. 2008. Optimization of humic acids coagulation with aluminum and iron(III) salts. Polish Journal of Environmental Study, 17(3), 397-403.
15. Matilainen A., Vepsäläinen M., Sillanpää M. 2010. Natural organic matter removal by coagulation during drinking water treatment: A review. Advances in Colloid and Interface Science, 159, 189-197.

16. Nowacka A., Włodarczyk-Makuła M. 2014. Impact of Selected Pre-Hydrolyzed Aluminum Coagulants on Improvingof Treated Water Quality. Rocznik Ochrona Środowiska, 16, 336-350.

17. Nowacka A., Włodarczyk-Makuła M., Macherzyński B. 2014. Comparison of effectiveness of coagulation with aluminum sulfate and pre-hydrolyzed aluminum coagulants. Desalin. Water Treat., 52, 3843-3851.

18. Piekutin J. 2013. Removal of petroleum hydrocarbons from water. Ann. Set Environ. Prot., 13, 2468-2478.

19. Pietrzyk A., Papciak D. 2018. The effectiveness of organic matter removal in unit processes of the technological groundwater treatment system. E3S Web Conf., 44

20. Pisarek I., Głowacki M. 2015. Quality of groundwater and aquatic humic substances from main reservoire of ground water. J. Ecol. Eng., 16(5), 46-53.

21. Rucka K., Solipiwko-Pieścik A., 'Wolska M. 2019. Efectiveness of humic substance removal during the coagulation process. SN Appl. Sci., 1:535 https://doi.org/10.1007/s42452-019-0541-1.

22. Sadrnourmohamadi, M., Gorczyca, B. 2015. Effects of ozone as a stand-alone and coagulation-aid treatment on the reduction of trihalomethanes precursors fromhigh DOC and hardness water. Water Res., 73, 171-180.

23. Sillanpää M., Ncibi M.C., Matilainen A., Vepsäläinen M. 2018. Removal of natural organic matter in drinking water treatment by coagulation: a comprehensive review. Chemosphere, 190, 54-71.

24. Szlachta M., Adamski W. 2009. Effects of natural organic matter removal by integrated processes: Alum coagulation and PAC-adsorption Water Sci Technol., 59(10), 1951.

25. Świderska-Bróż M., Rak M., Mołczan M., Biłyk A. 2008. Effct of the basicity of aluminium coagulants and the $\mathrm{pH}$ of the water on the removal of organic pollutants. Ochrona Środowiska, 30(4), 29-33.

26. Świetlik J., Dąbrowska A., Raczyk-Stanisławiak U., Nawrocki J. 2004. Reactivity of natural organic matter fraction with chlorine dioxide and ozone. Wat. Res., 38(3), 547-558.

27. Tekerlekopoulou A. G., Pavlou S., Vayenas D.V. 2013. Removal of ammonium, iron and manganese from potable water in biofiltrationunits: A review.J. Chem. Technol. Biotechnol., 88, 751-773.

28. Yan M., Wang, D. Ni J., Qu J., Chow Ch.W.K., Liu H. 2008. Mechanism of natural organic matter removal by polyaluminum chloride: Effct of coagulant particle size and hydrolysis kinetics. Wat. Res., 42, 3361-3370. 